\title{
The sense of coherence, social support and quality of life among patients with inflammatory bowel disease*
}

\section{Poczucie koherencji i wsparcie społeczne a jakość życia u chorych na nieswoiste zapalenia jelit}

\author{
Jakub Bieńkowski ${ }^{凶}$, Agata Rudnik, Mariola Bidzan \\ Uniwersytet Gdański, Instytut Psychologii, ul. Jana Bażyńskiego 4, 80-309 Gdańsk \\ University of Gdansk, Institute of Psychology \\ $\triangle$ jbienkowski94@gmail.com
}

\begin{abstract}
Introduction: Inflammatory bowel disease (IBD) is a group of chronic digestive system conditions which significantly influence the everyday life of patients. Exhausting intestinal discomfort might cause a strong feeling of distress and lowers the quality of life. This study was based on the question: how are the sense of coherence, social support, socio-demographic variables and the duration of disease related to the quality of life of individuals suffering from IBD?

Materials and methods: Thirty-nine individuals suffering from IBD were examined: 21 with ulcerative colitis, 17 with Crohn's disease and 1 with microscopic colitis. The participants completed a socio-demographic survey, and Life Orientation Questionnaire (SOC-29) and Berlin Social Support Scales (BSSS) questionnaires.
\end{abstract}

\section{ABSTRAKT}

Wstęp: Nieswoiste zapalenia jelit (NZJ) to grupa przewlekłych schorzeń układu pokarmowego, które znacznie wpływają na życie codzienne pacjentów. Uciążliwe dolegliwości jelitowe mogą powodować duży dyskomfort i obniżać jakość życia. Przeprowadzono badanie, aby sprawdzić czy poczucie koherencji, wsparcie społeczne, zmienne socjodemograficzne i czas trwania choroby wiążą się z jakością życia chorych na NZJ

Materiały i metody: Łącznie zbadano 39 osób: 21 z wrzodziejącym zapaleniem jelita grubego, 17 z chorobą Leśniowskiego-Crohna i 1 z mikroskopowym zapaleniem jelita. Pacjenci wypełnili ankietę socjodemograficzną, kwestionariusz Life Orientation Questionnaire (SOC-29) i Berlin Social Support Scales (BSSS).
The quality of life was examined by the Functional Assessment of Cancer Therapy-Gastric (FACT-Ga) questionnaire.

Results: The overall rate of the sense of coherence with its components and the available instrumental and emotional support was found to be significantly connected to the patients' quality of life. The level of education differentiated the examined patients in terms of the quality of life.

Conclusions: Psychological resources can play a significant role in the assessment of the impact of chronic disease on patients' everyday life. It is important to focus on their importance in raising the quality of life of the patients.

Keywords: ulcerative colitis; Crohn's disease; chronic disease; digestive system diseases; clinical psychology.
Do zbadania jakości życia wykorzystano metodę Functional Assessment of Cancer Therapy-Gastric (FACT-Ga).

Wyniki: Ogólny wskaźnik poczucia koherencji i jego składowe oraz dostępne wsparcie instrumentalne i emocjonalne są związane z jakością życia pacjentów i jej wymiarami. Poziom wykształcenia różnicuje badanych pod względem jakości życia. Wnioski: Zasoby psychologiczne chorych mogą odgrywać znaczącą rolę w ocenie wpływu choroby przewlekłej na życie codzienne. Ważne jest skupienie się na ich znaczeniu, aby poprawić jakość życia pacjentów.

Słowa kluczowe: wrzodziejące zapalenie jelita grubego; choroba Leśniowskiego-Crohna; choroba przewlekła; choroby układu pokarmowego; psychologia kliniczna.

\section{INTRODUCTION}

Chronic diseases are stressful and significantly reduce patient functioning in many aspects of everyday life. Not only do they cause distress and are a physical burden, but also trigger negative emotions [1]. Such conditions also affect the mental health, often leading to depression and anxiety [2].

Inflammatory bowel disease (IBD), including Crohn's disease, ulcerative colitis and microscopic colitis, are chronic conditions with spontaneous remissions and recurrences [3]. Their clinical picture is dominated by chronic bloody diarrhoea,

nausea, abdominal pain and weight loss $[4,5]$. The incidence of IBD (approx. 10 per 100000 individuals) [6], as well as the nature of those most at risk (the young, educated, living in good socio-economic conditions) [7], make these conditions a common subject of research in modern medicine. A popular indicator showing the impact of the condition on a patients' life is health-related quality of life (HRQL), understood as the effects of the condition and its treatment, objectively or subjectively perceived by the patient, both in medical (disease symptoms, physical fitness) and non-medical aspects (ability to function within society and family and at work) [8]. A high

* This manuscript is a part of the MA thesis by Jakub Bieńkowski entitled "Quality of life among patients with inflammatory bowel diseases", successfully defended at the Department of Social Sciences at the University of Gdańsk. Thesis supervisor: prof. dr hab. Mariola Bidzan. The original work contains: 69 pages, 16 figures, 9 tables and 74 references. 
HRQL indicates that despite the condition, the patient considers themselves to be a fit and highly functioning individual, while a low HRQL value indicates the patient experiences some limitations in everyday life [9].

The quality of life index conditioned by the state of health is also helpful in the search for psychological factors that may be associated with the increase in symptoms or the degree of adapting to the condition, such as a sense of coherence or social support.

According to Antonovsky, the sense of coherence is the individual's conviction that all stimuli they receive are logical, explainable, and fully predictable; that the individual has the resources to cope with these stimuli, and that it is worth their effort and commitment [10]. Accordingly, the sense of coherence consists of 3 dimensions:

- a sense of comprehensibility (perceiving the flow of information as understood, coherent, and ordered),

- $\quad$ sense of manageability (the degree to which an individual believes that they have the means and resources to meet their expectations),

- $\quad$ sense of meaningfulness (the conviction about the meaningfulness of life, or that it is worth putting effort into everyday activities and expectations) [10]. In recent years, this concept has gained great popularity and become the subject of numerous studies aiming to determine its relationship to the patients' quality of life $[11,12,13]$.

The sense of social support is best described as the degree to which a person believes that social support networks can provide help when experiencing stress or difficult circumstances [14]. Numerous studies show that social support is related to our psychological well-being, i.e. the positive assessment of our life, self-development, relationships with others, autonomy, and life goals [15], and is a predictor of quality of life in many conditions, e.g. kidney disease [16] or cancer [17]. Many researchers, in order to better characterize this concept, distinguish between the perceived, received and sought support. Perceived social support is the individual's internal belief about with whom and where to seek help, that is, a belief about the availability of support. Received social support is the help objectively received in a specific situation or at a specific time, and seeking social support means a need for support, i.e. an actual willingness and readiness to accept support [10].

Previous studies on the quality of life of gastroenterological patients, including IBD and irritable bowel syndrome (IBS), have proven that the quality of life of individuals suffering from IBS is significantly reduced in areas such as the individual's physical, emotional and social functioning (including performing social roles), mental health, and general sense of wellbeing. Further to that, studies show that up to $70 \%$ of patients with IBS may suffer from depression, anxiety, and chronic stress, and the sleep quality of a large proportion of patients is diminished [18]. Statistics concerning the mental health of patients with IBD are equally hardly optimistic - up to $20 \%$ of patients may develop depression - and the risk is highest in women with severe symptoms [19]. It has been proven that
IBD significantly reduces the quality of life of patients in the emotional, social and general spheres and causes a number of intestinal ailments discussed earlier [20]. It is worth noting that women more strongly experiencing a diminishing quality of life caused by the condition, the rapid development of the condition, and from relapses, have additional negative impacts on their quality of life [21]. Haapamäki et al. [22] and Moradkhani et al. [23] conducted other studies focusing on the question of socio-demographic factors and their impact on the quality of life in chronic conditions.

The aim of this study was to determine whether the quality of life of patients suffering from IBD is related to their psychological resources - their sense of coherence and social support. Investigating the nature of the relationship between these constructs and the patients' quality of life can help medical staff and psychologists counteract the negative effects of the chronic condition by working with the individuals' psychological resources. In order to determine the relationship between the sense of coherence and social support and the patients' quality of life, the following research question was posed: how are the sense of coherence, social support, socio-demographic variables and the duration of the disease related to the quality of life of individuals suffering from IBD?

\section{MATERIALS AND METHODS}

The study was conducted between June and December 2017. The majority of the study group were patients of the Independent Public Health Care Centre of the Ministry of Internal Affairs in Gdańsk and the J. K. Łukowicz Specialist Hospital in Chojnice. The remaining non-hospitalized patients were examined at their homes. The inclusion criteria included being over 18 years old and being diagnosed with IBD. All patients had given their written consent to participate in the study. The respondents were informed that the obtained data would only be used for scientific purposes. All respondents were given the researcher's e-mail address, should they be interested in the results of the study. Where needed, a conversation aimed at eliminating stress preceded the study. Once the questionnaires were completed, psychological support was also provided. The demographic characteristics of the respondents are presented in Table 1.

Patients were examined using the following methods:

1. Life Orientation Questionnaire (SOC-29) by Aaron Antonovsky (1993) - this tool consists of 29 items which should be addressed on a 7-point scale different for each statement. It also allows examination of the level of all 3 components of the sense of coherence: comprehensibility, manageability, and meaningfulness. The Polish version of the scale has satisfactory psychometric properties (Cronbach alpha 0.87);

2. Berlin Social Support Scales (BSSS) by Ralf Schwarzer and Ute Schulz (2006) - this method is used to measure different types of social support. Part A of the method used in the study contains 17 items which should be addressed 
TABLE 1. Demographic characteristics of the study group

\begin{tabular}{|c|c|}
\hline Parameters & $M, n(\%)$ \\
\hline Age & $M=31.47 \pm 10.17$ \\
\hline \multicolumn{2}{|l|}{ Gender } \\
\hline Female & $25(64.1 \%)$ \\
\hline
\end{tabular}

\section{Education}

\begin{tabular}{ll}
\hline Higher $25(64.1 \%)$ \\
\hline
\end{tabular}

\section{Relationship status}

In a partnership / married

$27(69.2 \%)$

\section{Duration of disease}

$22(56.4 \%)$

on the scale from 1-4, where 1 means entirely untrue and 4 means entirely true. The sum of individual answers indicates the level of social support available, the need for social support or seeking social support - the higher the score, the higher the level of support. The reliability of the Polish version of the tool, tested on a population of patients ( $\mathrm{n}=$ 632), is high, Cronbach alpha for subscales: available social support $\alpha=0.90$, need for social support $\alpha=0.71$, seeking social support $\alpha=0.80$;

3. Functional Assessment of Cancer Therapy-Gastric (FACT$\mathrm{Ga}$ ) questionnaire, part of the FACIT Measurement System - this method is used to assess various aspects of the current quality of life of patients with gastrointestinal cancer, but can also be used for patients with other enterological diseases. It consists of 46 items divided into 5 subscales:

- physical state,

- family and social life,

- emotional state,

- functioning in everyday life,

- other ailments.

This tool also allows calculation of an overall indicator of the quality of life of the patient. For each position, the patient must respond on a scale of $0-4$, where 4 means not at all, and 0 means very much. Cronbach alpha 0.87 .

Analysis of the results and descriptive statistics were carried out using the IBM $₫$ SPSS $₫$ Statistics 25 program. The homogeneity of variance in the groups was verified by a Levene homogeneity test, the normality of the variable distribution was determined by a Shapiro-Wilk test, and the size of the groups was compared by a $\chi^{2}$ test. Analyses have shown that the variables do not meet parametric test norms, therefore intergroup comparisons were made using a U Mann-Whitney test. A Spearman rank correlation coefficient was used to determine the correlation between variables.

\section{RESULTS}

Analyses show that the general indicator of the sense of coherence with all dimensions is significantly associated with the general quality of life and its areas (Tab. 2). The strongest relationships were observed between the general sense of coherence, manageability, comprehensibility, meaningfulness, and the emotional state subscale. A linear regression analysis was carried out and this showed that the sense of coherence is a significant predictor of the overall quality of life of patients [F (1.37) = 36.68, $\left.\mathrm{p}<0.001, \mathrm{R}^{2}=0.50\right]-$ Table 3 .

It was observed that the available emotional support is related to the dimensions family and social life and emotional state, while available instrumental support is related to the overall quality of life of patients and the dimensions family and social life, emotional state and functioning in everyday life. The patients' quality of life is most strongly associated with the demand for support, which is also significantly related to all areas of quality of life beyond family and social life. A positive relationship also occurred between seeking support and the subscale family and social life. These results are shown in Table 4.

The level of education turned out to be an important factor differentiating patients in terms of quality of life - individuals with higher education report a higher quality of life than those with primary, vocational, post-secondary or secondary education. Other variables, including gender, marital status

TABLE 2. Correlation between the sense of coherence and quality of life and its dimensions

\begin{tabular}{|c|c|c|c|c|}
\hline Parameters & Feeling of coherence & Comprehensibility & Manageability & Meaningfulness \\
\hline Overall quality of life & $0.70^{* *}$ & $0.69 * *$ & $0.65^{\star *}$ & $0.57^{* *}$ \\
\hline Physical state & $0.53^{* *}$ & $0.51^{* *}$ & $0.46^{* *}$ & $0.48^{* *}$ \\
\hline Family and social life & $0.44^{* *}$ & $0.36^{*}$ & $0.46^{* *}$ & $0.37^{*}$ \\
\hline Emotional state & $0.72^{* *}$ & $0.74^{* *}$ & $0.72 * *$ & $0.53^{* *}$ \\
\hline Functioning in everyday life & $0.67 * *$ & $0.60 * *$ & $0.51^{* *}$ & $0.69 * *$ \\
\hline Other conditions & $0.62 * *$ & $0.65^{* *}$ & $0.57^{* *}$ & $0.50 * *$ \\
\hline
\end{tabular}

${ }^{*} p<0.05 ;{ }^{* *} p<0.01$ 
TABLE 3. Linear regression outcome with general quality of life as dependent variable

\begin{tabular}{ccccc} 
Predictor & $\mathbf{R}$ & $\mathbf{R}^{2}$ & $\begin{array}{c}\text { Standard error in } \\
\text { estimation }\end{array}$ & $\mathbf{p}(37)$ \\
\hline Sense of coherence & 0.704 & 0.496 & 25.012 & 6.031 \\
\hline
\end{tabular}

TABLE 4. Correlations between social support and the quality of life and its dimensions

\begin{tabular}{lccc}
\multicolumn{1}{c}{ Parameters } & $\begin{array}{c}\text { Available emotional } \\
\text { support }\end{array}$ & $\begin{array}{c}\text { Available instrumental } \\
\text { support }\end{array}$ & Need for support \\
\hline Overall quality of life & 0.24 & $0.34^{*}$ & $0.58^{* *}$ \\
\hline Physical state & -0.01 & 0.14 & $0.43^{* *}$ \\
\hline Family and social life & $0.55^{* *}$ & $0.65^{* *}$ & 0.26 \\
\hline Emotional state & $0.36^{*}$ & $0.36^{*}$ & $0.58^{* *}$ \\
\hline Functioning in everyday life & 0.19 & $0.38^{* *}$ & 0.01 \\
\hline Other conditions & 0.10 & 0.15 & -0.07 \\
\hline
\end{tabular}

* $p<0.05 ;{ }^{* *} p<0.01$

and duration of the disease, did not prove statistically significant in differentiating the groups in terms of perceived quality of life (Tab. 5).

\section{DISCUSSION}

The results demonstrate that the sense of coherence is a significant predictor for the general indicator of IBD patient quality of life. The strong relationship between the sense of coherence and its components and the patient quality of life has been confirmed by many other studies, such as Freitas et al. [11], in which the general indicator of the sense of coherence also proved to be a predictor of all aspects of quality of life, including somatic symptoms of the disease.
Other studies have shown a positive relationship between the sense of coherence and self-efficacy, as well as an inverse relationship with the level of fatigue in patients [24]. Subjective perception of the world as predictable, as well as the belief in having the resources to confront the world, is therefore a well-documented resource that allows one to effectively deal with the condition and the resultant limitations to everyday life. The examined aspects of social support (available support, demand for support, and seeking support) proved to be strongly related to the selected aspects of the patients' quality of life. This points to the significant role played by support networks in the lives of patients - on one hand, emotional support can help patients in everyday life, and on the other - the strength of the symptoms is strongly associated with the need for support. The described relationships were also

TABLE 5. Mann-Whitney $U$ test results for the tested variable - overall quality of life

\begin{tabular}{|c|c|c|c|c|}
\hline Grouping variable & Group & Median range & $\mathbf{U}$ & $p$ \\
\hline \multirow{3}{*}{ Gender } & female & 18.12 & \multirow{3}{*}{128.00} & \multirow{3}{*}{0.17} \\
\hline & & & & \\
\hline & male & 23.36 & & \\
\hline \multirow{3}{*}{ Education } & primary - secondary & 14.36 & \multirow{3}{*}{96.00} & \multirow{3}{*}{0.02} \\
\hline & & & & \\
\hline & higher & 23.16 & & \\
\hline \multirow{2}{*}{ Relationship status } & In a relationship & 20.78 & \multirow{2}{*}{141.00} & \multirow{2}{*}{0.52} \\
\hline & single & 18.25 & & \\
\hline \multirow{2}{*}{ Duration of disease } & $<5$ years & 17.23 & \multirow{2}{*}{138.50} & \multirow{2}{*}{0.23} \\
\hline & > & & & \\
\hline
\end{tabular}


examined in other studies - it has been proven that the support provided by family, friends and others is significantly related to the quality of life of IBD patients [25]. Other studies have shown that perceived social support is a predictor of quality of life in patients with Crohn's disease and ulcerative colitis [23]. The analysis of previous studies on the impact of gastroenterological diseases on the lives of patients shows that these conditions completely disrupt their everyday functioning, affecting both the social and emotional spheres $[18,20]$. The rate at which the sickness develops, the severity of the symptoms, and the length of remission and relapse periods are also significant [21].

Additional factors that should be taken into account when considering the impact of chronic conditions on the lives of patients are undoubtedly socio-demographic variables. The research conducted by our team did not show that gender, education, or marital status differentiate the respondents in terms of quality of life, although based on previous research, women could be expected to report a lower level of quality of life index than men $[23,26,27,28,29]$. One hypothesis explaining a lower quality of life in women is the overall greater role of psychological factors and their impact on the lives of women, as well as the greater tendency of women to report concerns, worries and limitations caused by the condition. Research also indicates that quality of life in gastroenterological diseases decreases with age, which may be associated with longer periods of sickness and more frequent coexistence of IBD with other conditions at an older age $[27,28]$. It should be taken into account that longer periods of sickness may be associated with better adjustment, as evidenced by numerous studies that showed that patients up to 1 year after the diagnosis report a lower quality of life than those who have lived with the condition for a longer period [22, 26]. One variable differentiating patients in terms of quality of life is the level of education. This may be related to the patient's higher income, which facilitates treatment and contact with doctors, as well as lower levels of expenses-related stress. It is also possible that a higher education level makes it easier for patients to find support groups, information about the disease and its course, which reduces stress and helps them cope with the condition. Another, equally important factor differentiating gastroenterological patients in terms of quality of life is the country of residence $[30,31]$. This can be explained by the vast differences between healthcare systems, costs, and the quality of care provided to patients with chronic conditions.

Because of the challenge of reaching out to chronic disease sufferers, this study was conducted on a relatively small group, hence the results should be approached with suitable caution. It also appears important to define whether the respondents are in remission or relapse, as the latter is associated with far greater health and mental consequences than the former. The results of the study have shown numerous significant correlates of the non-specific IBD sufferers' quality of life. A study on the sense of coherence and social support networks may prove to be a valuable aid in determining the impact of chronic diseases on patients' lives. The area of psychological resources and social support can also be fields of intervention aimed at helping the patients in the fight against everyday difficulties resulting from the disease. Establishing the indicators of gastroenterological patients' quality of life appears to be invaluable, because chronic disease is not only a source of pain and emotional tension, but also a factor that permanently alters the patients' lives.

\section{CONCLUSIONS}

1. The sense of coherence and social support are significantly related to the quality of life of patients with IBD.

2. The level of education differentiates the respondents in terms of quality of life. Patients having higher education perceive their quality of life as better.

\section{REFERENCES}

1. Ostrzyżek A. Jakość życia w chorobach przewlekłych. Probl Hig Epidemiol 2008;89(4):467-70.

2. Seigel WM, Golden NH, Gough JW, Lashley MS, Sacker IM. Depression, selfesteem, and life events in adolescents with chronic diseases. J Adolesc Health 1990;11(6):501-4.

3. Muszyński J, editor. Gastroenterologia. Warszawa: Oficyna Wydawnicza Akademii Medycznej w Warszawie; 2005.

4. Wojtuń S, Gil J, Szwed $七$, Dyrla P. Podstawowe objawy i różnicowanie nieswoistych chorób zapalnych jelit. Pediatr Med Rodz 2014;10(1):61-6.

5. Szczuko M, Konecka N, Kikut J, Klimczyk W. Sposób żywienia nastoletnich pacjentów chorych na wrzodziejące zapalenie jelita grubego, chorobę Leśniowskiego-Crohna i celiakię a morfologia krwi. Pomeranian J Life Sci 2017;63(4):67-76. doi: 10.21164/pomjlifesci.334.

6. Lakatos L, Kiss LS, David G, Pandur T, Erdelyi Z, Mester G, et al. Incidence, disease phenotype at diagnosis, and early disease course in inflammatory bowel diseases in Western Hungary, 2002-2006. Inflamm Bowel Dis 2011;17(12):2558-65.

7. Sonnenberg A. Disability from inflammatory bowel disease among employees in West Germany. Gut 1989;30(3):367-70.

8. Schipper H. Quality of life: principles of the clinical paradigm. J Psychosoc Oncol 1990;8(2-3):171-85.

9. Radecka B. Jakość życia uwarunkowana zdrowiem - znaczenie i sposoby oceny u chorych na nowotwory. Curr Gynecol Oncol 2015;13(3):172-9.

10. Heszen I, Sęk H. Psychologia zdrowia. Warszawa: Wydawnictwo Naukowe PWN; 2007.

11. Freitas TH, Andreoulakis E, Alves GS, Miranda HLL, Braga LLBC, Hyphantis $\mathrm{T}$, et al. Associations of sense of coherence with psychological distress and quality of life in inflammatory bowel disease. World J Gastroenterol 2015;21(21):6713-27.

12. Pasikowski T. Stres i zdrowie. Podejście salutogenetyczne. Poznań: Wydawnictwo Fundacji Humaniora; 2000.

13. Szatkowska K, Dreger E, Basińska MA. Poczucie koherencji i więź z Bogiem osób chorych onkologicznie a ich jakość życia. Psychoonkologia 2016;20(1):37-46.

14. Sęk H, Cieślak R, editors. Wsparcie społeczne, stres i zdrowie. Warszawa: Wydawnictwo Naukowe PWN; 2004.

15. Emadpoor L, Lavasani MG, Shahcheraghi SM. Relationship between perceived social support and psychological well-being among students based on mediating role of academic motivation. Int J Ment Health Addict 2015;14(3):284-90

16. Masood A, Kamran F, Rashid S, Mazahir S. Life-orientation, subjective well-being and social support as predictors of quality of life in patients with end stage renal disease. Bangladesh J Med Sci 2017;16(3):346-53.

17. Li M, Yang YL, Liu L, Wang L. Effects of social support, hope and resilience on quality of life among Chinese bladder cancer patients: a crosssectional study. Health Qual Life Outcomes 2016;14:73. doi: 10.1186/ s12955-016-0481-z. 
18. Baniasadi N, Dehesh MM, Mohebbi E, Hayatbakhsh Abbasi M, Oghabian Z. Assessing the sleep quality and depression-anxiety-stress in irritable bowel syndrome patients. Arq Gastroenterol 2017;54(2):163-6.

19. Panara AJ, Yarur AJ, Rieders B, Proksell S, Deshpande AR, Abreu MT, et al. The incidence and risk factors for developing depression after being diagnosed with inflammatory bowel disease: a cohort study. Aliment Pharmacol Ther 2014;39(8):802-10.

20. Prisco V, Iannaccone T. Inflammatory bowel disease and quality of life: psychopathological variants. Recenti Prog Med 2017;108(2):83-9.

21. Casellas F, Arenas JI, Baudet JS, Fábregas S, García N, Gelabert J, et al. Impairment of health-related quality of life in patients with inflammatory bowel disease: a Spanish multicenter study. Inflamm Bowel Dis 2005;11(5):488-96.

22. Haapamäki J, Turunen U, Roine RP, Färkkilä MA, Arkkila PET. Impact of demographic factors, medication and symptoms on disease-specific quality of life in inflammatory bowel disease. Qual Life Res 2009;18(8):961-9.

23. Moradkhani A, Beckman LJ, Tabibian JH. Health-related quality of life in inflammatory bowel disease: psychosocial, clinical, socioeconomic, and demographic predictors. J Crohns Colitis 2013;7(6):467-73.

24. Opheim R, Fagermoen MS, Jelsness-Jørgensen LP, Bernklev T, Moum B. Sense of coherence in patients with inflammatory bowel disease. Gastroenterol Res Pract 2014;2014:1-9.

25. Katz L, Tripp DA, Ropeleski M, Depew W, Curtis Nickel J, Vanner S, et al. Mechanisms of quality of life and social support in inflammatory bowel disease. J Clin Psychol Med Settings 2016;23(1):88-98.
26. Jäghult S, Saboonchi F, Johansson UB, Wredling R, Kapraali M. Identifying predictors of low health-related quality of life among patients with inflammatory bowel disease: comparison between Crohn's disease and ulcerative colitis with disease duration. J Clin Nurs 2011;20(1112):1578-87.

27. Bernklev T, Jahnsen J, Lygren I, Henriksen M, Vatn M, Moum B. Healthrelated quality of life in patients with inflammatory bowel disease measured with the short form-36: psychometric assessments and a comparison with general population norms. Inflamm Bowel Dis 2005;11(10):909-18.

28. Casellas F, López-Vivancos J, Casado A, Malagelada JR. Factors affecting health related quality of life of patients with inflammatory bowel disease. Qual Life Res 2002;11(8):775-81.

29. Sainsbury A, Heatley RV. Review article: psychosocial factors in the quality of life of patients with inflammatory bowel disease. Aliment Pharmacol Ther 2005;21(5):499-508.

30. Ghosh S, Mitchell R. Impact of inflammatory bowel disease on quality of life: Results of the European Federation of Crohn's and Ulcerative Colitis Associations (EFCCA) patient survey. J Crohns Colitis 2007;1(1):10-20.

31. Haapamäki J, Turunen U, Roine RP, Färkkilä MA, Arkkila PE. Finnish patients with inflammatory bowel disease have fewer symptoms and are more satisfied with their treatment than patients in the previous European survey. Scand J Gastroenterol 2008;43(7):821-30. 